\title{
Colonic intussusception caused by an ulcerating lipoma in an adult: A rare case report and literature review.
}

\author{
Yingying Zhuang ${ }^{1,2 \#, ~ S h i p e n g ~ L i u ̈ ~}{ }^{3 \#}$ Yuntao $\mathrm{Shi}^{4}$, Zhonghong Wang ${ }^{3}$, Wei Huang ${ }^{2}$, Daoyan $\mathbf{L u}^{2}$, \\ Jiandong Zhang ${ }^{2}$, Dan Kong ${ }^{2}$, Bin Wang ${ }^{*}$
}

${ }^{1}$ Shandong Medical Imaging Research Institute, Shandong University, No. 324, Jingwu Road, Jinan, Shandong, PR China

${ }^{2}$ Department of Medical Imaging, Huai'an First People's Hospital, Affiliated to Nanjing Medical University, No. 6, Western Beijing Road, Huaiyin District, Huai'an, Jiangsu, PR China

${ }^{3}$ Department of Gastroenterology, Hongze Huai'an District People's Hospital, No.102, Dongfeng Road, Hongze District, Jiangsu, PR China

${ }^{4}$ Department of Gastroenterology, Huai'an First people's Hospital, Affiliated to Nanjing Medical University, No. 6, Western Beijing Road, Huaiyin District, Huai' an, Jiangsu, PR China

${ }^{5}$ Medical Imaging Research Institute, Binzhou Medical University, No.346, Guanhai Road, Laishan District, Yantai, Shandong, PR China

${ }^{\#}$ These authors contributed equally to these work

\begin{abstract}
Intestinal lipomas are rare nonepithelial tumors that are typically small in size and detected incidentally. Colonic intussusception is an uncommon complication of colonic lipoma. A 56 y old woman visited our emergency room with sudden onset of intermittent abdominal cramps. A CT scan showed a $5.0 \mathrm{~cm}$, nodular, homogenous, hypodense structure in the hepatic flexure of the colon as the lead point of an intussusception. The hypodense structure was suggestive of a colonic lipoma, and the tumor was suspected to be the cause of the intestinal intussusception. Laparoscopic exploration was performed, and the pathology demonstrated a mature submucosal colonic lipoma. In addition to the case report, we discuss the role of imaging modalities in diagnosing neoplasms and for assessing the clinical behavior of lipomas when symptomatic.
\end{abstract}

Keywords: Intussusception, Lipoma, Computed tomography.

Accepted on December 7, 2017

\section{Introduction}

Colonic lipoma is a rare benign tumor with a reported incidence ranging from $0.15 \%$ to $4.4 \%$ [1]. The most common position of colonic lipoma is the right hemicolon, followed by the descending and transverse colon. Although the majority of colonic lipomas are small and asymptomatic, some cause symptoms such as abdominal pain, diarrhea, bowel obstruction and intussusception [1,2]. Here, we present a case report of a giant colonic lipoma causing ascending-colonic intussusception and discuss the role of imaging modalities for diagnosing neoplasms to assess the clinical behavior of lipomas when symptomatic.

\section{Case Report}

The patient described in this case report provided written informed consent for both the report and the accompanying images.

A 56 y old woman with a 5 y history of obstipation and intermittent abdominal pain was admitted to the emergency department. Her abdominal pain had been exacerbated in the past week and was accompanied by a change in bowel habits. Mucous and blood were present in the stool starting three days prior to admission. Moderate, paroxysmal and cramp-like pain was present in the right hypochondrium and radiated to the back, without signs of peritonitis. She did not report any history of anemia, dyspeptic symptoms, episodes of diarrhea, or rectal bleeding. No disease history was reported. The physical examination was unremarkable. Laboratory test results showed elevated inflammatory parameters and a high 
level of C-reactive protein $(10.8 \mathrm{mg} / \mathrm{l})$. Tumor makers were within the normal ranges. She also underwent Digital Radiography (DR) and Computed Tomography (CT) examinations of the abdomen. The DR showed no obvious abnormalities. The CT scan showed a $5.0 \mathrm{~cm}$, nodular, homogenous, hypodense structure in the hepatic flexure of the colon, suggestive of a colonic lipoma (Figure 1A), as a lead point of an intussusception (Figure 1B). The lipoma was suspected as the cause of the intestinal intussusception, and laparoscopic exploration was performed. Subsequent histopathological examination confirmed that the mass was a lipoma with ulceration and reactive changes without evidence of malignancy (Figure 2). A segment resection was performed in the hepatic flexure of the colon with end-to-end anastomosis. The postoperative course was uneventful, and the patient was discharged from the hospital on the $7^{\text {th }}$ postoperative day. The patient was in a healthy condition after 1 year of follow-up.

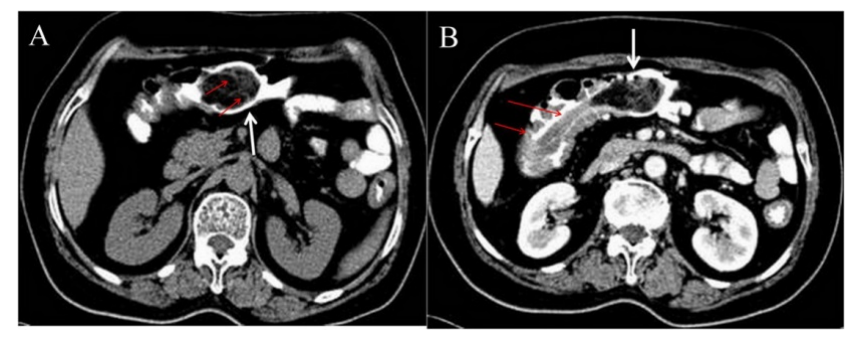

Figure 1. A. A CT scan of the abdomen revealing an ovoid fatty density mass (white arrow) with septa (red arrow) in the colon. B. Colo-colonic intussusception secondary to a lipoma. A transverse contrast material-enhanced computed tomography scan of the abdomen showing the typical multilayered appearance of an intussusception. The intussusceptum containing a lipoma (white arrow) as a lead point and part of the ascending colon was surrounded by the dilated intussuscipiens (red arrow).

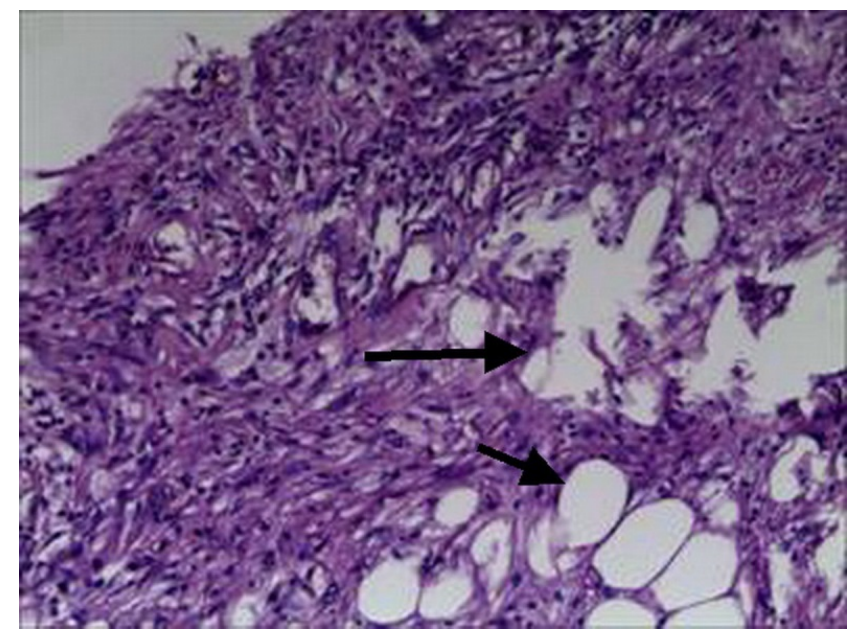

Figure 2. Histopathological examination of the resected specimen revealing a mass consisting of mature adipocytes (arrow), fibrous cells and ulceration of the overlying colonic mucosa with no heterogeneous nucleus or seedless division in the submucosal layer (hematoxylin and eosin staining; magnification X100).

\section{Discussion}

Lipomas are the most common non-epithelial neoplasms of the gastrointestinal tract and can be found in any part of the gut [1-3]. Colonic lipomas are benign submucosal tumors composed of mature adipose tissue and were first reported by Bauer in 1757 [2,3]. After reviewing the literature for the most recent cases (Table 1) [1-13], we concluded that most lipomas range in size from $2 \mathrm{~mm}$ to $30 \mathrm{~cm}$ and that the majority of patients are between 50 and 70 y of age, with a female predominance. Colonic lipomas are typically asymptomatic or minimally symptomatic when less than $2.0 \mathrm{~cm}$ in size, and they are usually detected during endoscopy, surgery, or autopsy. A prior study indicated that only $32 \%$ to $50 \%$ of cases are diagnosed preoperatively [4-5]. In contrast, large lipomas generally produce symptoms, including abdominal pain, diarrhea, bowel obstruction, and obstipation. These symptoms are primarily caused by chronic intermittent ileocolonic or colo-colonic intussusceptions [5-8]. Furthermore, large lipomas can have ulcerations and may cause gastrointestinal bleeding as a result of pressure necrosis in the overlying mucosa [4].

Intussusception remains a rare condition in adults. Only 5\% of intussusceptions are found in the adult population, and $1 \%$ of these are bowel obstructions. Approximately $90 \%$ of intussusceptions in adults have an organic cause, with primary carcinoma representing $65-70 \%$ of all cases [6]. Colonic lipoma as a leading cause is uncommon.

Imaging modalities can aid in the preoperative diagnosis of colonic lipomas. Barium enemas usually show ovoid, welldemarcated filling defects and smooth sub-mucosal masses [7-9]. The "squeeze sign" describes when a lipoma adopts a fusiform appearance with colonic peristalsis; such deformation can result from external pressure or peristalsis. During colonoscopy, colonic lipomas typically appear as a submucosal mass covered by intact mucosa. Elevation of mucosa using biopsy forceps ("tent sign"), indentation of mucosa after pressing on it ("cushion sign"), or extrusion of fat after biopsy ("naked fat sign") are also observed [10-12]. Lipomas can be difficult to differentiate from a malignant lesion due to the associated necrotic mucosa, ulceration, and relatively hard texture of the lesion. When a lesion is actively bleeding, endoscopic biopsy may not be safe or reliable. In most cases, CT can clearly reveal the characteristic fatty densitometric features of lipomas and definitively diagnose intestinal lipomas, avoiding unnecessary endoscopy or surgery. On CT, lipomas usually appear as well-circumscribed submucosal masses with homogeneous fat attenuation and thin fibrous septa. CT can also detect colonic lipoma complications, such as intussusception. However, intussuscepted lipomas may not demonstrate normal fat attenuation and may have a heterogeneous appearance reflective of the degree of infarction and fat necrosis present at the time of radiologic evaluation. If prominent fibrous septa and modularity are evident, the imperative differential diagnosis is liposarcoma [4]. Magnetic Resonance Imaging (MRI) is particularly suited to detecting fatty lesions because signal intensity characteristics typical for 
adipose tissue are evident on T1-weighted and fat-suppressed images. However, MRI is seldom used for detecting and studying intestinal neoplastic lesions $[1-2,13,14]$.

There is an urgent need for doctors to address symptomatic patients with large lipomas who are developing intussusceptions. Ultrasound is a suitable method for this purpose because it is easy to perform, reproducible, and less invasive than other methods. On ultrasound, an abdominal mass with a "donut" or "target" sign in which the outermost layer represents the sheath and the multilayer ring structure represents the invaginated intestinal segment, is pathognomonic for the presence of an intussusception $[13,14]$. Recent reports have shown that abdominal CT scanning has a diagnostic sensitivity of $58-100 \%$ and a specificity of $57-71 \%$, and this method is considered the "gold standard" for diagnosis [6,7]. CT can clearly reveal the typical characteristics of uniform tumor density with thin septa, clear borders, and no enhancement. Additionally, a "target" sign or "sausageshaped" mass on CT, depending on the angle of the beam relative to the intussusception, represents an inner central area of invaginated intussusceptum that is surrounded by mesenteric fat and associated vasculature, all of which are surrounded by the thick-walled intussuscipiens. In the case of lipoma, the tumor is the lead point within the lumen of the intussuscipiens. Mesenteric vessels within the bowel lumen are also typically observed. Because of the ability to visualize these features, CT findings are very helpful when operating.

Asymptomatic small lipomas may not require intervention. Though spontaneous expulsion of lipomas through the rectum has been reported $[5,11,14]$, a small subgroup requires surgical intervention, including those with suspected malignancy, symptomatic lipomas, surgical emergencies such as intussusceptions, and obstruction with ulceration and bleeding [7]. The management strategy for colonic lipomas mainly depends on the size, clinical symptoms, and preoperative diagnosis.

The indication of endoscopic resection of colonic lipomas is still a subject of controversy [8]. Various endoscopic procedures including snare resection, ESD, and unroofing or the endoloop technique have been introduced recently for safe resection. Khorashad et al. and Geraci et al. suggest that endoscopic removal of colonic lipomas larger than $2 \mathrm{~cm}$, even if is technically difficult because of their vascular nature, large pedicle, and size, is safe, feasible and effective using standard polypectomy technique with the availability of endoloop and hemoclips in case of uneventful complications or to prevent it $[10,12]$.

Recently, laparoscopic procedure and minilaparotomy approach were reported as an alternative to conventional laparotomy used in removal of large colonic lipomas with all the known advantages of minimally invasive procedures [8]. In the article, there is a case about adopting laparoscopic procedures to excise the large colonic lipoma which goes well, and the postoperative recovered well.

Symptomatic colonic lipomas are very rare and present with a variety of symptoms depending on location and size, often leading to misdiagnosis. A correct and timely diagnosis is important to avoid complications. CT can assist in providing confirmatory diagnosis of a colonic lipoma. Surgical resection remains the treatment of choice, with an excellent prognosis and no reports of recurrence.

Table 1. Characteristics of reported cases of adult colonic lipomas.

\begin{tabular}{|c|c|c|c|c|c|c|c|c|}
\hline Case & Sex & Age (y) & Symptom & Examination & Tumor location & Size $(\mathbf{c m})$ & Treatment & First author and Journal \\
\hline \multirow[t]{2}{*}{1} & $\mathrm{~F}$ & 49 & $\begin{array}{l}\text { Intermittent } \\
\text { abdominal pain }\end{array}$ & $\begin{array}{l}\mathrm{CT} \text {, colonoscopy, barium } \\
\text { enema }\end{array}$ & $\begin{array}{l}\text { Hepatic flexure } \\
\text { of the colon }\end{array}$ & 9 & $\begin{array}{l}\text { Laparocsopic } \\
\text { surgery }\end{array}$ & Moussa \\
\hline & & & & & & & & $\begin{array}{ll}\text { Surg Laparosc } & \text { Endosc } \\
\text { Percutan Tech [1] } & \end{array}$ \\
\hline \multirow[t]{2}{*}{2} & M & 65 & $\begin{array}{l}\text { Altered bowel habits and } \\
\text { rectal bleeding }\end{array}$ & CT, colonoscopy & Sigmoid colon & 4 & Laparocsopic & Moussa \\
\hline & & & & & & & & $\begin{array}{ll}\text { Surg Laparosc } & \text { Endosc } \\
\text { Percutan Tech [1] } & \end{array}$ \\
\hline \multirow[t]{2}{*}{3} & $\mathrm{~F}$ & 65 & $\begin{array}{l}\text { Intermittent abdominal } \\
\text { pain }\end{array}$ & CT, colonoscopy & $\begin{array}{l}\text { Transverse } \\
\text { colon }\end{array}$ & $4.0 \times 5.0$ & Laparotomy & Zhou \\
\hline & & & & & & & & Oncol Lett [2] \\
\hline \multirow[t]{2}{*}{4} & $\mathrm{~F}$ & 47 & Constipation & CT, colonoscopy & $\begin{array}{l}\text { Descending } \\
\text { colon }\end{array}$ & $13.0 \times 5.0$ & $\begin{array}{l}\text { Laparocsopic } \\
\text { surgery }\end{array}$ & Bagherzadeh \\
\hline & & & & & & & & $\begin{array}{l}\text { Gastroenterol hepatol Bed } \\
\text { ench [3] }\end{array}$ \\
\hline \multirow[t]{2}{*}{5} & $\mathrm{~F}$ & 40 & $\begin{array}{l}\text { Mucous and blood } \\
\text { present in stool }\end{array}$ & Colonoscopy, US & Sigmoid colon & $5.0 \times 5.0 \times 5.0$ & Laparotomy & Roy \\
\hline & & & & & & & & Birdem Med J [4] \\
\hline \multirow[t]{2}{*}{6} & M & 39 & $\begin{array}{l}\text { A mass prolapsed } \\
\text { through the anal canal }\end{array}$ & CT, colonoscopy & Sigmoid colon & $10 \times 8 \times 7.5$ & Laparotomy & Kose \\
\hline & & & & & & & & Oncol Lett [5] \\
\hline
\end{tabular}




\begin{tabular}{|c|c|c|c|c|c|c|c|c|}
\hline \multirow[t]{2}{*}{7} & \multirow[t]{2}{*}{$M$} & \multirow[t]{2}{*}{38} & \multirow{2}{*}{$\begin{array}{l}\text { Hypogastric pain, } \\
\text { constipation, loss of } \\
\text { appetite and weight }\end{array}$} & \multirow{2}{*}{ CT, colonoscopy } & \multirow{2}{*}{$\begin{array}{l}\text { Splenic flexure } \\
\text { of the colon }\end{array}$} & \multirow[t]{2}{*}{$7.0 \times 5.0 \times 4.5$} & \multirow[t]{2}{*}{ Resection } & \multirow{2}{*}{$\begin{array}{l}\text { Zare-Khormizi } \\
\text { Pathologica [6] }\end{array}$} \\
\hline & & & & & & & & \\
\hline \multirow[t]{2}{*}{8} & \multirow[t]{2}{*}{ M } & \multirow[t]{2}{*}{50} & \multirow[t]{2}{*}{$\begin{array}{l}\text { Intermittent } \\
\text { pain }\end{array}$} & \multirow[t]{2}{*}{$\mathrm{CT}$} & \multirow[t]{2}{*}{$\begin{array}{l}\text { Transverse } \\
\text { colon }\end{array}$} & \multirow[t]{2}{*}{$6.5 \times 4.0 \times 4.5$} & \multirow[t]{2}{*}{$\begin{array}{l}\text { Laparocsopic } \\
\text { surgery }\end{array}$} & Kwag \\
\hline & & & & & & & & Ann Coloproctol [7] \\
\hline \multirow[t]{2}{*}{9} & \multirow[t]{2}{*}{$\mathrm{F}$} & \multirow[t]{2}{*}{54} & \multirow[t]{2}{*}{ Severe abdominal pain } & \multirow[t]{2}{*}{ CT, colonoscopy } & \multirow{2}{*}{$\begin{array}{l}\text { Ascending } \\
\text { colon }\end{array}$} & \multirow[t]{2}{*}{$6.0 \times 4.0 \times 3.5$} & \multirow{2}{*}{$\begin{array}{l}\text { Laparocsopic } \\
\text { surgery }\end{array}$} & Kwag \\
\hline & & & & & & & & Ann Coloproctol [7] \\
\hline \multirow[t]{2}{*}{10} & M & 65 & Rectal bleeding & CT, colonoscopy & Cecum & $3.5 \times 2.1 \times 2$ & Laparocsopic & Boler \\
\hline & & & & & & & & Am J Case Rep [8] \\
\hline 11 & M & 65 & Fatigue and deyspnea, & CT, colonoscopy & Cecum & $3.3 \times 1.8 \times 2$ & Laparocsopic & Boler \\
\hline & & & 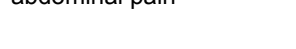 & & & & surgeriy & Am J Case Rep [8] \\
\hline 12 & M & 63 & $\begin{array}{l}\text { Abdominal distention and } \\
\text { bloody stools }\end{array}$ & CT, colonoscopy & $\begin{array}{l}\text { Transverse } \\
\text { colon }\end{array}$ & $7.8 \times 6.5 \times 3.5$ & $\begin{array}{l}\text { Laparocsopic } \\
\text { surgery }\end{array}$ & Boler \\
\hline & & & & & & & & Am J Case Rep [8] \\
\hline 13 & M & 74 & $\begin{array}{l}\text { Abdominal pain and } \\
\text { discomfort }\end{array}$ & CT, colonoscopy & Cecum & $7.2 \times 6.0 \times 5.5$ & $\begin{array}{l}\text { Laparocsopic } \\
\text { surgery }\end{array}$ & Boler \\
\hline & & & & & & & & Am J Case Rep [8] \\
\hline 14 & $\mathrm{~F}$ & 34 & $\begin{array}{l}\text { Intermittent abdominal } \\
\text { pain }\end{array}$ & $\begin{array}{l}\mathrm{CT} \text {, barium enema, } \\
\text { colonoscopy }\end{array}$ & $\begin{array}{l}\text { Ascending } \\
\text { colon }\end{array}$ & $6 \times 5 \times 4.5$ & Laparotomy & Atmatzidis \\
\hline & & & & & & & & Case Rep Surg [9] \\
\hline 15 & M & 45 & $\begin{array}{l}\text { Iron deficiency anemia, } \\
\text { flesh rectal bleeding }\end{array}$ & Colonoscopy & Sigmoid colon & 8 & Endoscopic & Khorashad \\
\hline & & & & & & & & J Res Med Sci [10] \\
\hline 16 & M & 38 & Hematochezia, & Colonoscopy , barium & Transverse & $7.5 \times 4.5$ & Spontaneous & Ishiyama \\
\hline & & & & & & & & Endoscopy 2011 [11] \\
\hline 17 & M & 60 & Abdominal pain & Colonoscopy & Sigmoid colon & 3.5 & Endoscopic & Geraci \\
\hline & & & & & & & & $\begin{array}{l}\text { Case Rep Gastroenterol } \\
\text { [12] }\end{array}$ \\
\hline 18 & M & 31 & $\begin{array}{l}\text { Intermittent abdominal } \\
\text { pain, rectal bleeding }\end{array}$ & CT & $\begin{array}{l}\text { Descending } \\
\text { colon }\end{array}$ & $5.5 \times 5 \times 3.5$ & Laparotomy & Barchetti \\
\hline & & & & & & & & $\begin{array}{l}\text { Eur Rev Med Pharmacol } \\
\text { Sci [13] }\end{array}$ \\
\hline 19 & $\mathrm{~F}$ & 82 & Abdominal pain & Colonoscopy & Transverse & 2 & Endoscopic & Tomiki \\
\hline & & & & & & & & Case Rep Gastroenterol \\
\hline 20 & M & 74 & $\begin{array}{l}\text { Abdominal pain and } \\
\text { melena }\end{array}$ & Colonoscopy & $\begin{array}{l}\text { Transverse } \\
\text { colon }\end{array}$ & 5 & $\begin{array}{l}\text { Endoscopic } \\
\text { resection }\end{array}$ & Tomiki \\
\hline & & & & & & & & Case Rep Gastroenterol \\
\hline 21 & $\mathrm{~F}$ & 36 & $\begin{array}{l}\text { Intermittent abdominal } \\
\text { pain and diarrhea }\end{array}$ & $\mathrm{CT}$ & Sigmoid colon & $4 \times 4 \times 3$ & Laparotomy & Paul \\
\hline & & & & & & & & J Case Rep Images Surg \\
\hline & & & & & & & & World J Gastroenterol \\
\hline 23 & M & 48 & Abdominal pain & Colonoscopy & Ascending & $7.5 \times 4.5 \times 4.0$ & Endoscopic & Lee \\
\hline & & & & & & & & World J Gastroenterol \\
\hline 24 & M & 35 & $\begin{array}{l}\text { Intermittent abdominal } \\
\text { pain, rectal bleeding }\end{array}$ & CT & Sigmoid colon & 2.5 & Laparotomy & Mohamed \\
\hline & & & & & & & & Int J Surg Case Rep \\
\hline 25 & M & 49 & $\begin{array}{l}\text { Abdominal pain and } \\
\text { constipation }\end{array}$ & $\mathrm{CT}$ & $\begin{array}{l}\text { Hepatic flexure } \\
\text { of the colon }\end{array}$ & 5 & Laparotomy & Toumi \\
\hline
\end{tabular}




\begin{tabular}{|c|c|c|c|c|c|c|c|c|c|}
\hline & & & & & & & & \multirow[b]{2}{*}{ Tunis Med } \\
\hline & & & & & & & & & \\
\hline \multirow[t]{2}{*}{26} & \multirow[t]{2}{*}{$\mathrm{F}$} & \multirow[t]{2}{*}{59} & \multirow[t]{2}{*}{$\begin{array}{l}\text { Progressive } \\
\text { abdominal pain }\end{array}$} & \multirow[t]{2}{*}{ CT } & & \multirow[t]{2}{*}{$\begin{array}{l}\text { Hepatic flexure } \\
\text { of the colon }\end{array}$} & \multirow[t]{2}{*}{$6 \times 5$} & \multirow[t]{2}{*}{ Laparotomy } & Toumi \\
\hline & & & & & & & & & Tunis Med \\
\hline \multirow[t]{2}{*}{27} & \multirow[t]{2}{*}{$\mathrm{F}$} & \multirow[t]{2}{*}{73} & \multirow{2}{*}{$\begin{array}{l}\text { Intermittent } \\
\text { pain }\end{array}$} & \multirow{2}{*}{ CT, colonoscopy } & & \multirow[t]{2}{*}{ lleocecal valve } & \multirow{2}{*}{$5.5 \times 3.0 \times 2.2$} & \multirow{2}{*}{$\begin{array}{l}\text { Endoscopic } \\
\text { resection }\end{array}$} & Kasaka \\
\hline & & & & & & & & & Endoscopy \\
\hline \multirow[t]{2}{*}{28} & \multirow[t]{2}{*}{$\mathrm{F}$} & \multirow[t]{2}{*}{34} & \multirow{2}{*}{$\begin{array}{l}\text { Intermittent abdominal } \\
\text { pain and constipation }\end{array}$} & CT, colonoscopy & & $\begin{array}{l}\text { Descending } \\
\text { colon }\end{array}$ & $5.3 \times 4.1 \times 4.6$ & Laparocsopic & Allos \\
\hline & & & & & & & & & Am J Case Rep \\
\hline 29 & $\mathrm{~F}$ & 68 & Abdominal discomfort & Colonoscopy & & Ascending & 0.9 & Endoscopic & Yeom \\
\hline & & & & & & & & & World J Clin Cases \\
\hline 30 & $\mathrm{~F}$ & 65 & Abdominal discomfort & Colonoscopy & & Ileocecal valve & $3 \times 3$ & Endoscopic & Kim \\
\hline & & & & & & & & & Clin Endosc \\
\hline 31 & $\mathrm{~F}$ & 46 & Abdominal discomfort & Colonoscopy & & Sigmoid colon & $3 \times 3$ & Endoscopic & Kim \\
\hline & & & & & & & & 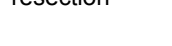 & Clin Endosc \\
\hline 32 & M & 48 & Abdominal discomfort & Colonoscopy & & $\begin{array}{l}\text { Ascending } \\
\text { colon }\end{array}$ & $4 \times 7$ & Endoscopic & Kim \\
\hline & & & & & & & & & Clin Endosc \\
\hline 33 & M & 55 & Severe abdominal pain & US, CT & & Ascending & $3 \times 3 \times 4.5$ & Laparotomy & Mouaqit \\
\hline & & & & & & & & & BMC Surg \\
\hline 34 & $\mathrm{~F}$ & 54 & $\begin{array}{l}\text { Intermittent abdominal } \\
\text { pain }\end{array}$ & US, CT & & $\begin{array}{l}\text { Descending } \\
\text { colon }\end{array}$ & 6 & Laparotomy & Grasso \\
\hline & & & & & & & & & Ann Ital Chir \\
\hline 35 & $\mathrm{~F}$ & 31 & Abdominal pain & $\begin{array}{l}\text { DR, US, } \\
\text { colonoscopy }\end{array}$ & CT, & $\begin{array}{l}\text { Descending } \\
\text { colon }\end{array}$ & 5.5 & Laparotomy & Bentama \\
\hline & & & & & & & & & Pan African Med J \\
\hline 36 & M & 74 & $\begin{array}{l}\text { Abdominal discomfort } \\
\text { and altered bowel habits }\end{array}$ & CT, colonoscopy & & $\begin{array}{l}\text { Hepatic flexure } \\
\text { of the colon }\end{array}$ & $3.3 \times 4.3 \times 3.4$ & $\begin{array}{l}\text { Laparocsopic } \\
\text { surgery }\end{array}$ & Coyne \\
\hline & & & & & & & & & JSCR \\
\hline 37 & M & 52 & $\begin{array}{l}\text { Abdominal pain and } \\
\text { constipation }\end{array}$ & $\mathrm{CT}$ & & $\begin{array}{l}\text { Ascending } \\
\text { colon }\end{array}$ & 5 & $\begin{array}{l}\text { Endoscopic } \\
\text { resection }\end{array}$ & Soares \\
\hline & & & & & & & & & Endoscopy \\
\hline 38 & $\mathrm{M}$ & 31 & $\begin{array}{l}\text { Intermittent abdominal } \\
\text { pain and rectal bleeding }\end{array}$ & CT, colonoscopy & & $\begin{array}{l}\text { Descending } \\
\text { colon }\end{array}$ & $5.5 \times 5 \times 3.5$ & Laparotomy & Barchetti \\
\hline & & & & & & & & & $\begin{array}{l}\text { Eur Rev Med Pharmacol } \\
\text { Sci }\end{array}$ \\
\hline 39 & M & 48 & Abdominal discomfort & Colonoscopy & & Transverse & 8 & Endoscopic & Jeong \\
\hline & & & & & & & & & Gut Liver \\
\hline 40 & $\mathrm{~F}$ & 47 & $\begin{array}{l}\text { Intermittent } \\
\text { abdominal pain }\end{array}$ & CT, colonoscopy & & $\begin{array}{l}\text { Hepatic flexure } \\
\text { of the colon }\end{array}$ & $5 \times 4 \times 4$ & Laparotomy & Lin \\
\hline & & & & & & & & & Endoscopy \\
\hline
\end{tabular}

\section{Acknowledgements}

We acknowledge all the doctors who helped with this work. This work was supported by the Science and Technology Bureau of Huai'an, Jiangsu Province, China (HAS2014009-3).

\section{References}

1. Moussa OM, Tee M, Khan AU, Selvasekar CR. Computerized tomography providing definitive diagnosis of colonic lipoma: a case series. Surg Laparosc Endosc Percutan Tech 2013; 23: 232-234.

2. Zhou XC, Hu KQ, Jiang Y. A 4-cm lipoma of the transverse colon causing colonic intussusception: A case report and literature review. Oncol Lett 2014; 8: 1090-1092.

3. Bagherzadeh SR, Sadeghi A, Rad N, Safari MT, Barzegar F. Colonic intussusception in descending colon: An unusual presentation of colon lipoma. Gastroenterol Hepatol Bed Bench 2016; 9: 93. 
4. Roy S, Mondal SK Maitra TK. Intussuscepted sigmoid colonic lipoma mimicking carcinoma rectum. Birdem Med J 2015; 5: 56-58.

5. Kose E, Cipe G, Demirgan S, Oguz S. Giant colonic lipoma with prolapse through the rectum treated by external local excision: a case report. Oncol Lett 2014; 8: 1377-1379.

6. Zare-Khormizi MR, Moghimi M, Pourrajab F. Giant pedunculated polypoid submucosal lipoma of the splenic flexure of colon: case report and review of the literature. Pathologica 2014; 106: 77-81.

7. Kwag SJ, Choi SK, Jung EJ, Jung CY, Jung SH, Park TJ, Ju YT. Surgical strategy for colonic intussusception caused by a giant colonic lipoma: a report of two cases and a review of the literature. Ann Coloproctol 2014; 30: 147-150.

8. Boler DE, Baca B, Uras C. Laparoscopic resection of colonic lipomas: When and why? Am J Case Rep 2013; 14: 270-275.

9. Atmatzidis S, Chatzimavroudis G, Patsas A, Papaziogas B, Kapoulas S, Kalaitzis S, Ananiadis A, Makris J, Atmatzidis K. Pedunculated cecal lipoma causing colo-colonic intussusception: a rare case report. Case Rep Surg 2012; 2012: 279213.

10. Khorashad AK, Hosseini SM, Gaffarzadegan K, Farzanehfar MR, Zivarifar HR. Endoscopic resection of large colonic lipomas assisted by a prototype single-use endoloop device. J Res Med Sci 2011; 16: 1511-1515.

11. Ishiyama $\mathrm{S}$, Tashiro $\mathrm{Y}$, Nagayasu $\mathrm{K}$, Niwa $\mathrm{K}$, Ono $\mathrm{S}$, Sugimoto K, Hata M, Kamiyama H, Komiyama H,
Takahashi M. Spontaneous disappearance of a giant colonic lipoma after endoscopic biopsy. Endoscopy 2011; 43: 16.

12. Geraci G, Pisello F, Arnone E, Sciuto A, Modica G, Sciume C. Endoscopic resection of a large colonic lipoma: case report and review of literature. Case Rep Gastroenterol 2010; 4: 6-11.

13. Barchetti F, Al Ansari N, De Marco V, Caravani F, Broglia L. Giant lipoma of descending colon diagnosed at CT: report of a case. Eur Rev Med Pharmacol Sci 2010; 14: 573-575.

14. Gollub MJ. Colonic intussusception: clinical and radiographic features. AJR Am J Roentgenol 2011; 196: 580-585.

15. Kang B, Zhang Q, Shang D, Ni Q, Muhammad F, Hou L, Cui W. Resolution of intussusception after spontaneous expulsion of an ileal lipoma per rectum: a case report and literature review. World J Surg Oncol 2014; 12: 143.

\section{*Correspondence to}

Bin Wang

Medical Imaging Research Institute

Binzhou Medical University

PR China 